\title{
THE INDONESIAN IBUISM IDEOLOGY AND GENDER PORTRAYAL: THE CASE OF THE 2015 RINSO ANTI-NODA TV COMMERCIAL
}

\author{
Jessica Odellia \\ Swiss German University, Indonesia \\ odeliajessi@gmail.com
}

\author{
Deborah N. Simorangkir \\ Swiss German University, Indonesia \\ deborah.simorangkir@sgu.ac.id
}

\begin{abstract}
In order to efficiently reach its targeted market, advertisers often package their messages in a manner so as to be easily understood. These massages often contain subliminal meanings using stereotypes. Based on Erving Goffman's work on gendered advertisement, this research analyzes the Rinso Anti Noda television commercial. Therefore, this research seeks to answer the following question: How is gender represented in the 2015 Rinso Anti Noda television commercial titled "Belajar Untuk Makan Sendiri" (Learning to eat by oneself)?

Based on the first author's research thesis under the supervision of the second author, involving a semiotic analysis on the Rinso Anti Noda TV commercial, complemented by In-depth interviews with a number of Indonesian mothers, data were then analyzed using the Goffman's gendered advertisement and Indonesia's Ibuism ideology perspectives. Results show that the role of a women in the advertising is as a mother and her place is in the domestic realm.
\end{abstract}

Keywords: Gender advertising, Indonesia, stereotypes, semiotic analysis. 


\section{INTRODUCTION}

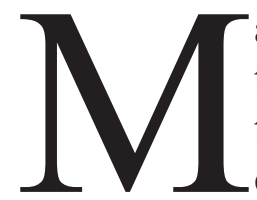
ass media is a powerful tool to influence and shape the audience's reality. The content of the media can be tailored according to the intended goals set by the people of power in the media. To achieve these goals, the message is embedded often at the cost of oversimplifying the portrayal of a social group within society (stereotyping). There are numerous types of media used in advertisements and one of the most predominant is the television. Historically, the practice of advertising in Indonesia was introduced by the Dutch, during the colonial era, by using local newspapers to advertise goods and publish official announcements made by the VOC (Vereenigde Oost Indische Compagnie). Since then, advertising has become a part of the everyday lives of Indonesia's commerce.

Televised advertisements in Indonesia started shortly after the first national broadcast television network, TVRI (Televisi Republik Indonesia) was launched in 1962. The first three televised advertisements were created by the advertising agency InterVisa. It took another twenty years for television advertising to completely dominate the network. The emergence of private broadcasting networks is the key reason for the rapid growth of television advertisements.

The consumer publics are the principal targets of advertisements, and women are at the center of the consumer spectrum. Consequently, gender biases are often used by advertisers because it is easier for advertisers to isolate their targeted market. For example, the use of women in cleaning product advertisements because they are believed to identify with their role as mothers or housewives.

There are mainly three ways women are portrayed in the Indonesian media: As a figurine (pigura), as a trophy (pinggan), and/or as a socialite (pergaulan). The figurine aspect highlights femininity to intensify the woman's allure. As a trophy, a woman is identified by her role as a caretaker and a mother. As a socialite, a woman is seen as a social being that places high importance on reaching a certain social stratum (Sari, 2012). These portrayals could lead to a narrowed and superficial ideal of what an Indonesian woman is. Even so, they are still widely used in the media, especially in advertising. One recent example is the 2015 television commercial for Rinso Anti Noda (Rinso Anti-Stain) titled "Belajar Untuk Bisa Makan Sendiri" (Learning to eat by oneself).

Originally branded Hudson's Soap, Rinso is a brand name for a laundry detergent that was first sold in 1918 in the United States. Rinso did not reach Indonesia until ten years later. In fact, Rinso was the pioneer of detergent soaps in Indonesia. For three consecutive years Rinso was awarded the Best Brand Award from 2003 to 2005. Today, Rinso offers a wide variety of detergent products starting from powder to liquid detergents down to detergents based on how the consumer does their laundry. Rinso Anti Noda, one of many variations offered by the Rinso brand, has been one of the best-selling detergent products in Indonesia since it was launched in 2009 (Rinso, 2016). To market its product, Rinso relies on various types of media ranging from print to online media to broadcast advertising. 
Based on Erving Goffman's work on gendered advertisement, this research provides an analysis of the Rinso Anti Noda television commercial. Therefore, this research seeks to answer the following question: How is gender represented in the 2015 Rinso Anti Noda television commercial titled "Belajar Untuk Makan Sendiri" (Learning to eat by oneself)? This research is based on the first author's (Odellia, 2016) thesis under the supervision of the second author.

\section{I.1. THE STATE IBUISM IDEOLOGY}

The ibuism ideology was first identified by the President Soeharto's New Order regime's declaration of The Five Obligations of a Woman (Panca Dharma Wanita): 1. A woman as a wife, who is a companion to her husband; 2. A woman as the conserver of the descendants; 3 . A woman as caretaker of the household; 4. A woman as an additional income earner for the family; and, 5. A woman as a citizen of the State (Wulandari \& Candria, 2012).

Devotion to the household and children is what the New Order regime define women to be. Based on this ideology, a woman is never identified as her own person. She is, instead, identified based on someone else (her husband and/or children) or something (family) (Rahmawati, 2014).

This ideology is also reflected by the media and thus, advertising in which gender portrayal becomes a commodity to market a product. In commercials for household products, women are almost always portrayed as mothers, and to emphasize that portrayal, either a husband or a child is always present
(Siregar \& Mahendro, 2011).

Moreover, she is depicted to be an active participant in the domestic realm (Bungin, 2001). These representations of women in the media is the result of hegemonic masculinity in which men are placed in a higher social position compared to women. Women are presented as subordinates and placed in a domestic context (Darwin, 1999). This adoption of women representations in the media is affiliated to society's patriarchal system (Madsen, 2000).

\section{I.2. GENDER IN THE MASS MEDIA}

The mass media is a vehicle for communication and dissemination of information to a wide range of audience (Tamburaka, 2012). It is a communication process that involves a sender and receiver model, where the sender is indicated as a single party sending a message to many receivers (Kawamoto, 2003). Traditionally there are three main functions of the media according to Harold Lasswell (1948): 1. Surveillance of the environment; 2 . Correlation between parts of the society corresponding to the environment; and, 3. Transmission of culture. McQuail (2010) narrows down the functions of the media to: information, correlation, continuity, entertainment, and mobilization. And because the media also has a function for entertainment, Wilbur Schramm (1964) defines the mass media as an instrument for promotion or advertisement to sell goods to the viewers.

Advertising itself is a persuasive presentation that aims to move its audience to take action. Kotler (1984) defined advertising as various forms 
of impersonal presentations and promotions by a promoter about ideas, goods and services. It also has the function to persuade the receiver to take action either now or some point the future (Richards \& Curran, 2002). Russo and Chaxel (2010) agree that persuasive messages have an influence on behavior regardless of the level of awareness of the message's receiver. Although the main focus of advertising is to market and promote a product, there are concerns regarding the content of the advertising when it portrays stereotypes. In regards to the topic of this research, the focus is on gender stereotypes as portrayed in advertising.

In advertising, both men and women are often represented using very contrast characteristics. Women in advertisements usually fall under these four characteristics: 1. Women are domestic creatures and therefore are placed in a household setting; 2 . Important decisions or actions are not done or made by women; 3. Women are dependent creatures in need of a men's protection; and 4. Women are regarded as a sexual objects by their counterparts (Courtney \& Lockeretz, 1971). Meanwhile, men tend to be portrayed in a role that is charismatic and independent (Vantomme et al, 2005).

Hegemonic masculinity plays a role in how masculinity and femininity are portrayed in the media. The concept of hegemonic masculinity itself refers to culturally referred traits of what is considered to be manly and the justification of male domination over women (Kareithi, 2014). Beasley (2008) suggests that hegemonic masculinity can be analyzed at three levels: 1. Local, in which hegemony is constructed from face to face interaction; 2. Regional, in which construction occurs in the cultural level; and, 3. Global, in which construction is world-wide. There is a lopsided view of how gender roles are depicted in the media.

\section{I.3. GENDER ADVERTISING AND GENDER DISPLAY}

Advertisements must be brief but effective, therefore advertisers use characters that are recognizable to reach the targeted goal of selling the product to a specific group (Ellis, 1996). When it comes to gender-tailored advertising, the key factors that the advertisers play on are femininity and masculinity (Popova, 2010). Gendered advertisements are extreme representations of what femininity and masculinity are. Based on the work of Erving Goffman, gender related advertisements paint a strange picture regarding gender relations (Goffman, 1979). Shields (2001) concurs this by stating that viewers would find this imbalance if they were to weigh in the relationship between advertising and reality.

Goffman looks closely at how advertisements display different types of body displays in advertisement is presented to the consumer. By examining imageries across various advertisements, Goffman has created six criteria on how to decode gender displays: relative size, feminine touch, the family, licensed withdrawal, the ritualization of subordination and functional ranking. These gender displays are media for information regarding the social identity, way of living, intentions and expectations (Burns, 1992). These depictions within the advertisements are the result of hyper-ritualization created 
by the advertisers, who standardize, exaggerate and simplify what already exists within society (Goffman, 1979). Hyper-ritualization created by advertisers in the most extreme form is seen as a support and a replication of the oppression of women (Murphy, 2003). Gender stereotypes lead to gender inequality, and this phenomenon is prevalent in every society in this world (Ellis, 1996).

\section{I.4. PORTRAYAL OF INDONESIAN WOMEN IN ADVERTISING}

Through advertising, aspects of masculinity and femininity can latch onto a product, thus creating the impression that certain products are either masculine or feminine. Advertisements for cigarettes, energy drinks or supplements, for instance, are synonymous with masculinity, whereas household or beauty products are synonymous with femininity (Rahmawati et al, 2010). This is because advertisements serve as socialization agents for cultural and social codes, and they do so using gender stereotypes (Anastasi, 1989). According to Kasiyan (2008), when it comes to the portrayal of women in advertising, there are three identified ways in which women are stigmatized: through their appeal, through the exaggeration of their body parts, and through the domestication of women (Kasiyan, 2008).

In spite of Indonesia's rich historical background, the gender role assigned to Indonesian women in advertising are not far from the context of women as domestic creatures and sexual objects. Indonesian women are portrayed in these five imageries: as a figurine (pigura), a trophy (pinggan), a pillar (pilar), a contest (peraduan) and a socialite (pergaulan) (Tamagola 1998). Most of the time women in advertising are placed in subordinate positions (Rahmawati et al, 2010). There is a narrow view of how women are portrayed in the media in terms of beauty, physicality, sexuality, emotion and dependency (Iriantara, 2008). Moreover, the representation of women in advertising is not far from their image as housewives (Siswati, 2015).

The subtlety of these portrayals often go unnoticed by the viewers (Budiman, 1999). To analyze the implicit messages in advertisements, the need to be able to identify signs within the content is crucial. Semiotics is a study of signs that can be applied to media studies. For the purpose of this research, Barthes's semiology study complements Goffman's concept of gender display in exploring the existence of gender roles within advertisements.

\section{RESEARCH METHOD}

\section{II.1. IN-DEPTH INTERVIEWS}

Because the research findings will be analyzed using the state ibuism perspective, the first method used in this research is the in-depth interview. In order to find out the perceptions of Indonesian women about motherhood, five mothers, aged 21 to 41 years old, were interviewed. The age and socioeconomic group of the respondents were chosen to match the age of the mother portrayed in the Rinso Anti Noda TV commercial.

\section{II.2. SEMIOTIC ANALYSIS}

Semiology is defined as the study of signs. The origin of the word semiology comes from the Greek word semion meaning sign (Berger 2000). Sobur (2009) defines semiology as a social study that comprehends the world as an interrelated 
system with 'signs' acting as its basic unit. On a daily basis, humans communicate using signs and the world is filled with signs. Signs act as representations that hold and convey meanings. Ferdinand de Saussure (1983) explains that signs are formed from the marriage between the signified and the signifier, while Barthes (1967), in Elements of Semiology (1967), concurs with Saussure but emphasized the various definitions of signs and the relations between the two relata (Barthes, 1967).

There are two major approaches in semiology, the dyadic model by Ferdinand de Saussure that connects the relations between the signified and the signifier and C.S. Pierce's triangle of meanings that consists of the triangular relationship between the representament, the interpretant and an object (Deledalle, 2000). The representament in Pierce's model is the form of the sign, the interpretant is the sense evoked by the sign, and the object is what is referred by the sign (Chandler, 2002).

In Saussure's semiotic model, the marriage between the signifier and the signified is called signification (Chandler, 2002). Signification is what happens when the mind is employed to interpret signs (Danesi, 2004). The signifier in Saussure's model is categorized as a something physical such as sounds, letters, or gestures, whereas the concept that represents the signifier is called the signified (Sebeok, 2001).

Saussure's dyadic model is the base for Barthes's Semiotic model. Barthes's model goes beyond the interpretation of signs, by creating an order of how a sign becomes a myth. In his model, Barthes adds another understanding of signs which he calls connotation and myth. Language holds a denotative meaning while a myth holds a more connotative meaning. In Barthes's view, mythologies transform a cultural value into a universally accepted value (Allen, 2003).

By understanding these connotative and denotative meanings, "text" readers could understand the use of linguistics and metaphors that are embedded within (Christomy \& Yuwono, 2004). According to Barthes, a sign could not stand on its own, it is a part of a system, which in turn, constructs its understanding of meanings. Barthes (1964) adopted Louis Hjelmslev's understanding of the different orders of signification. In his model, the first order of signification is where the denotative meaning is created. When the first order of sign interacts with another signified, it creates the connotative meaning (Barthes, 1964).

The object of this research is the 2015 television commercial of Rinso Anti Noda.

In this 30-second TV commercial, there are two main characters: the mother and the son. The commercial starts with a scene that includes both characters with the area setting of a kitchen. The mother is shown to be serving a bowl of food to the son. As the son begins to eat, she sits and begins to imagine his future occupation. Her daydream begins with the son becoming an architect, followed by becoming a doctor, and lastly, an inventor. The mother's daydream is interrupted when the son spatters his food on her clothes. The scene continues with the mother teaching the son to eat properly, followed by a sequence of the detergent product. The commercial ends with a scene that includes both mother and son placed in 
the same frame with the detergent.

The stages data gathering were conducted as such: First, the clip of the commercial was viewed to get an overall understanding of the story. Afterwards, the details from the clip were observed and relevant elements were categorically written down based on the time frame. The data were analyzed using Barthes's semiotic analysis of verbal and non-verbal elements. The thirty-second clip was catalogued into a collection of individual sequences. The assessment of the clip was divided into two elements: mise-en-scéne and dialogue.

\section{II.2.1. MISE-EN-SCÉNE}

To analyze a movie or a short clip such as a commercial, there are several aspects that the observer could assess: image, movement and sound. Mise-en-scéne falls under the imagery aspect of a movie. The word mise-en-scéne is literarily translated as "putting into the scene". Any visual elements within a scene is picked by the director as a tool for communication to the viewer to convey message both on a conscious and sub-conscious level (Logas $\&$ Muller, 2005).

\section{II.2.2. DIALOGUE}

The verbal communication aspect in a moving picture is the dialogue. It contains interaction between the characters with the sitting and also with the audience. Dialogue offers the viewers clues of what the characters are and where the plot of the story is going (Berliner, 1999). It is also used by the author of the script to convey emotions, perceptions, and thoughts of the portrayed characters (Walker, Lin, \& Sawyer 2012). In the context of advertisements and commercials, the dialogues exist to describe with the aim of persuasion (Verstergaard \& Schroder, 1985).
In a story-based advertisement, dialogue is a key factor in creating an authenticity and at the same time, communicate messages. It is easier for the audience to be convinced if a story is close to its reality (Chen, Chiu, \& Wang, 2009).

\section{RESEARCH FINDINGS}

\section{III.1. PERCEPTIONS OF MOTHERHOOD}

As previously explained, one lingering ideology about the ideal Indonesian woman is the ibuism ideology, which portrays the ideal woman as mothers, caretakers of the household and companions (Suryakusuma, 1987). Therefore, the researchers conducted in-depth interviews with 5 mothers in Jakarta regarding their perceptions of motherhood. When asked about what motherhood meant to them, all respondents agreed that motherhood is a woman's destiny:

"Motherhood is a responsibility and a destiny. A woman's destiny is to be a mother and a woman achieves perfection when she has a child and is able to take care of her child" (A).

"Aside from being a woman's destiny, motherhood is also God's will, because once we get married, whether we like it or not, we have to become mothers and we have to accept it" (B).

In carrying out their destiny, however, there are certain qualities that a good mother must have:

"A mother is the heart of the home, she has to be able to create a comfortable, safe and pleasant environment for the family. A good mother is also able to educate and be wise when dealing with the emotional development of the child" (C).

"I measure whether a mother is good or 
not based on how much time she spends with her child, and whether she singlehandedly takes care of the child, feed the child, and know the child's development. I don't feel like I'm a good mother because I find out about my son's developments from the nanny" (A).

Because the mother is considered as the one responsible for the comfort and wellbeing of the family, her most important duties include:

"To educate the child so she will have a good character...I want my child to be polite, grateful, willing to apologize, and be respectful to others" (D).

"A mother's main duty is to take care of all aspects of the child's every life cycle, because she gets pregnant, she gives birth, she breastfeeds, and indeed, taking care of the child and cleaning up the child's mess is her destiny, until the child finds his selfidentity, which, if the child is male, then until he finds a woman who can take care of him; and if the child is female, then until she finds a husband to take care of her" (A).

With such important duties, the respondents claim that lack of time is the main problem of motherhood:

"The lack of time for myself, feeling exhausted from taking care of children who are being naughty yet still trying to control my emotions when I'm feeling tired yet the children don't understand my situation" (E).

"It seems like 24 hours are not enough. I have to juggle between my work and paying attention to my child, so often times I work when my child is already asleep. The service of nannies become a main necessity when I have too much work to do" (C).
The results from the interviews show that the State ibuism ideology, which was championed by Soeharto's regime is still very much present today, as women still view motherhood as their destiny, and society views mothers as solely responsible for the comfort, wellbeing, and happiness of their families. Having seen these results, the next step is to analyze whether such ideology is also displayed in the Rinso Anti-Noda TV commercial.

\section{III.2. DENOTATIONS AND MYTHS}

In Barthes's method of semiotic analysis, a media text holds both a denotative also known as myth and a connotative meaning. The following are scenes collected into tables of sequence and analyzed using Barthes's semiotic method to answer the research question regarding gender representation and stereotypes: 


\section{Table 1. Sequence 1}

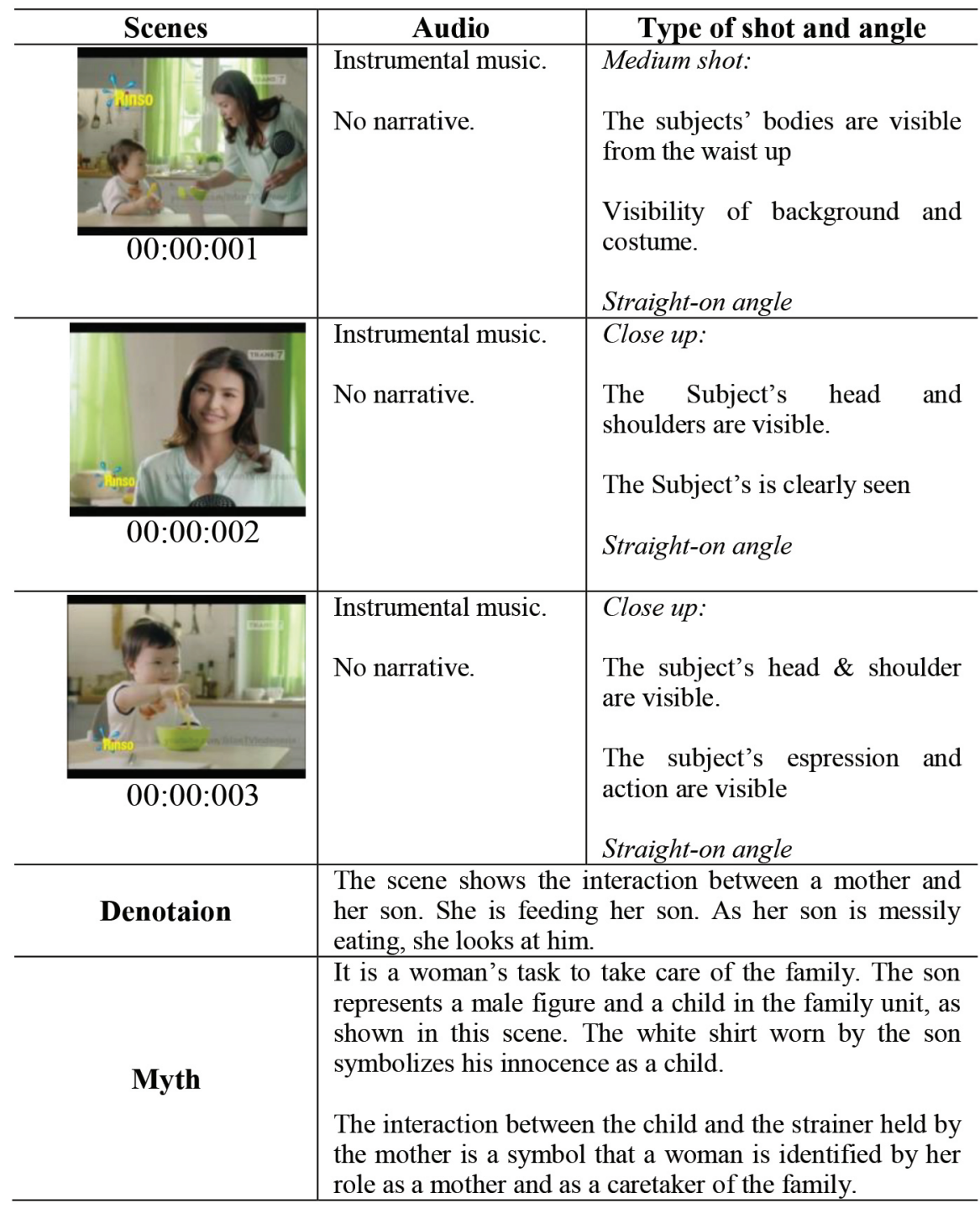


Table 2. Sequence 2

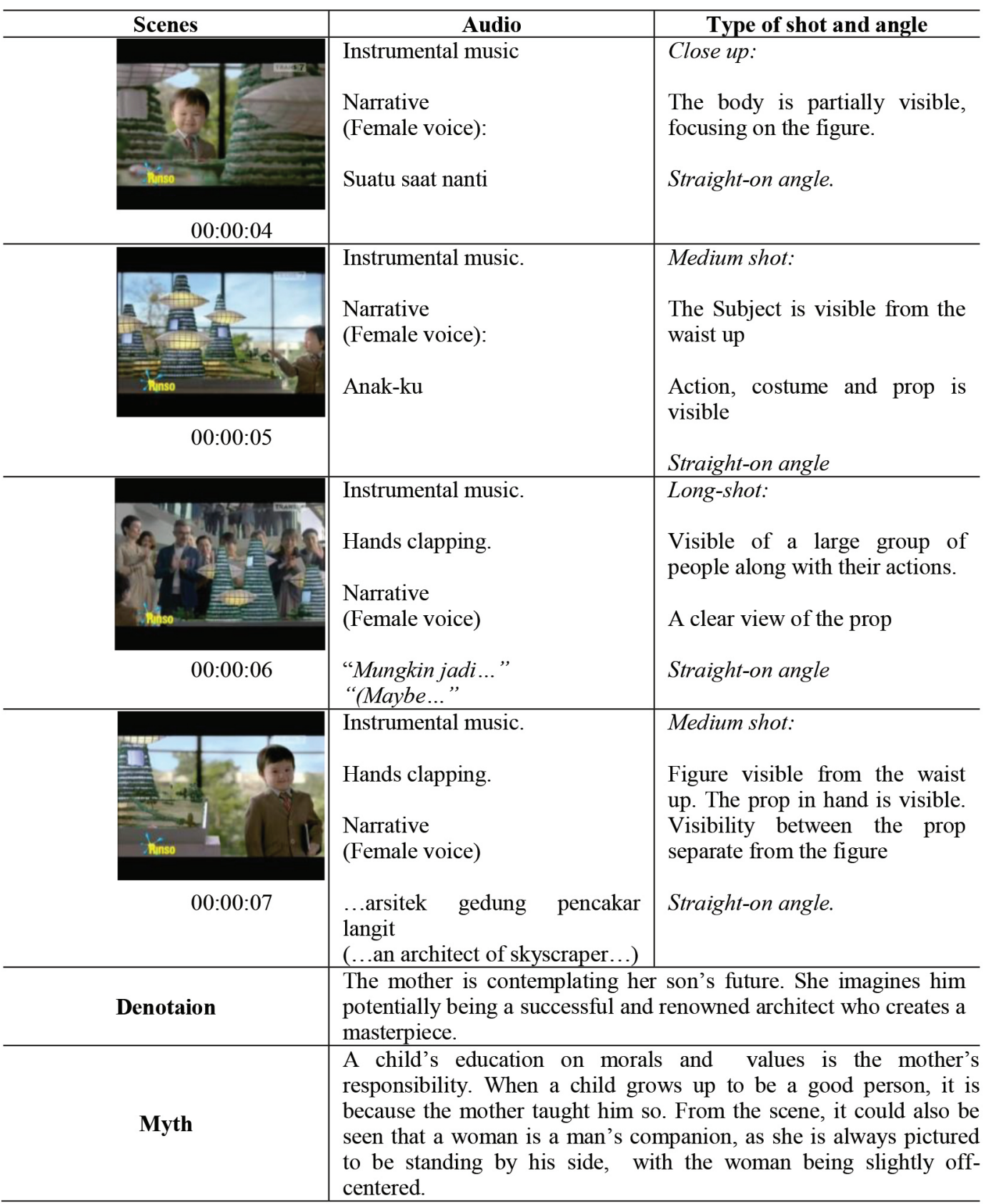


Table 3. Sequence 3

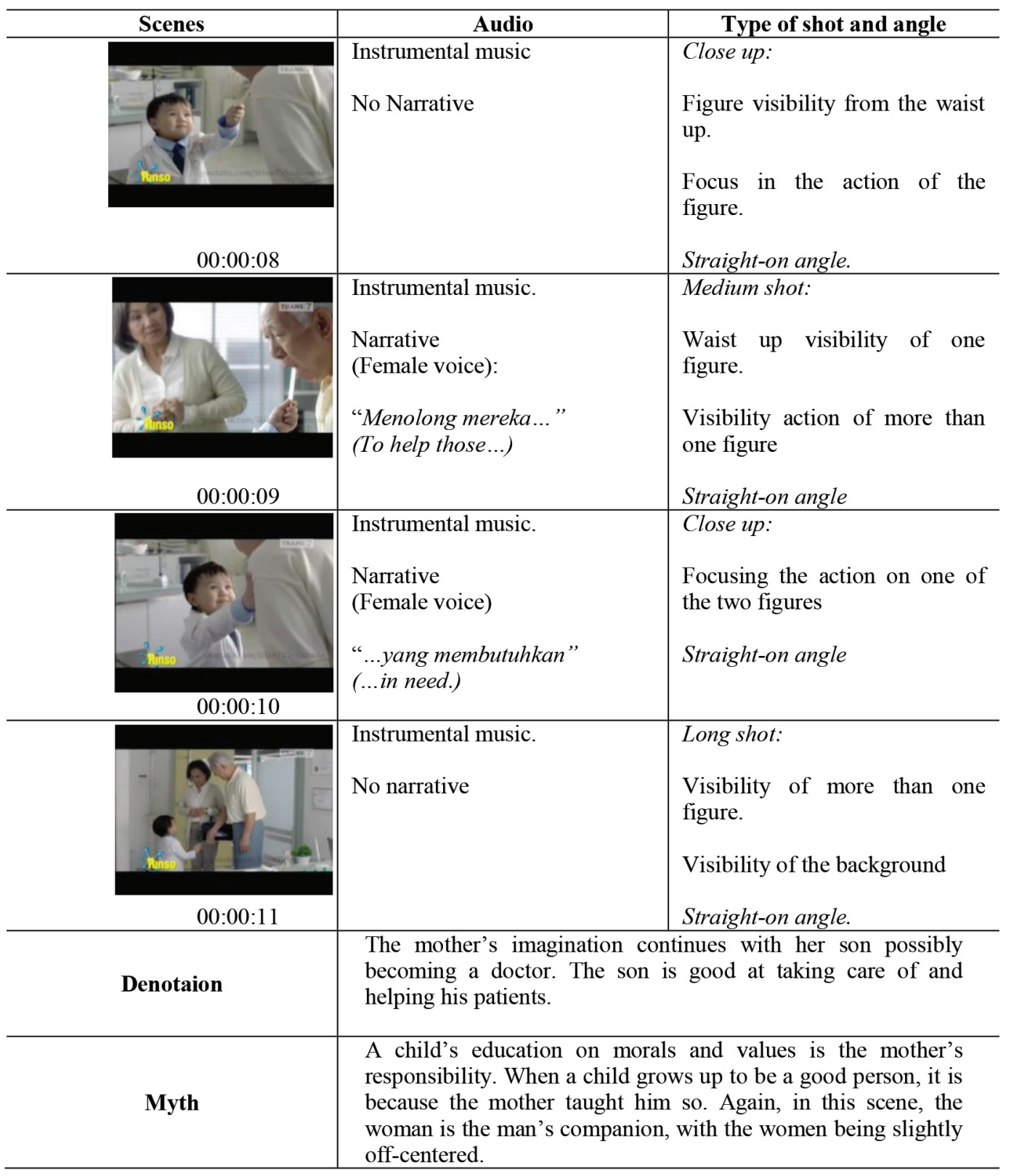


Table 4. Sequence 4

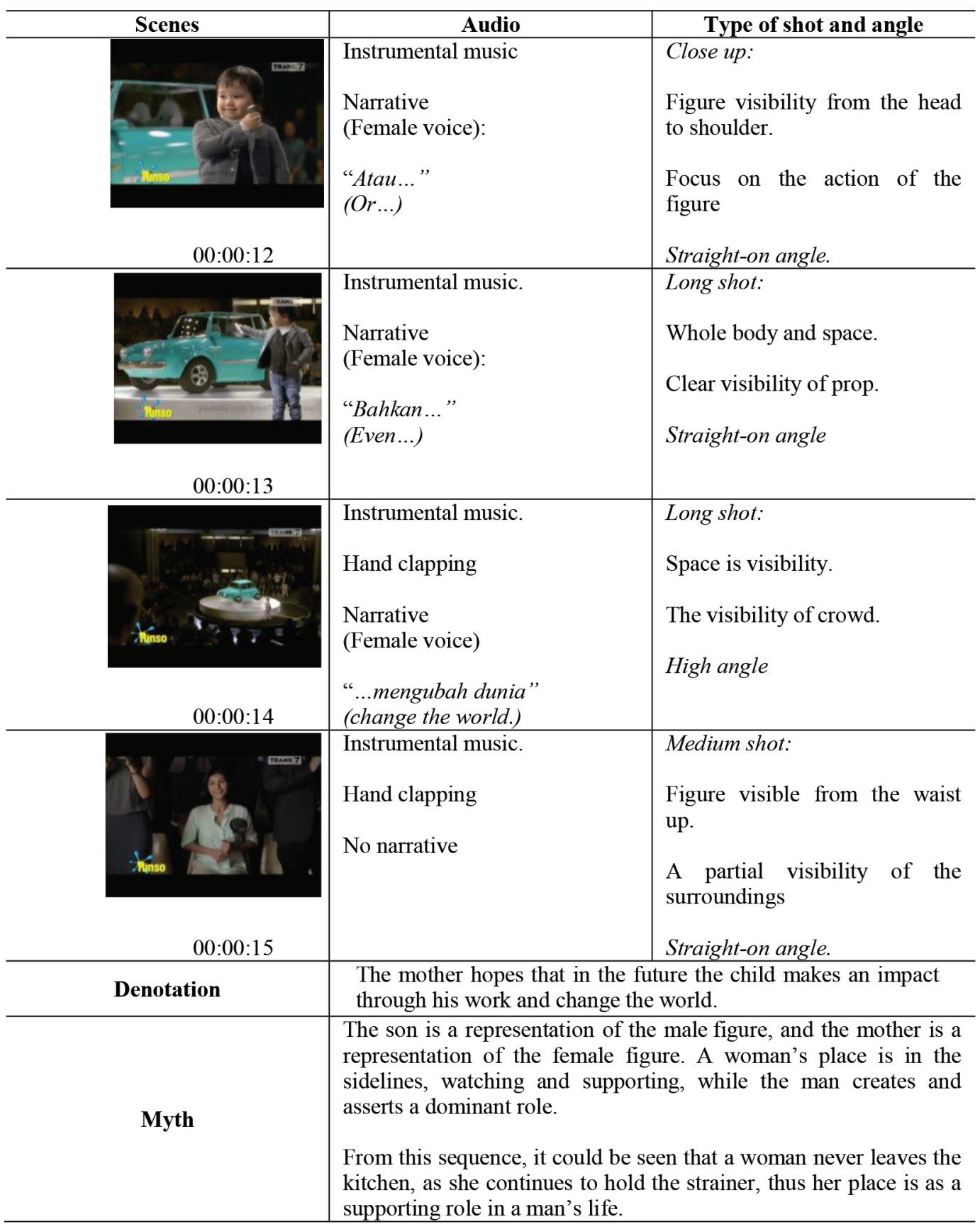


Table 5. Sequence 5

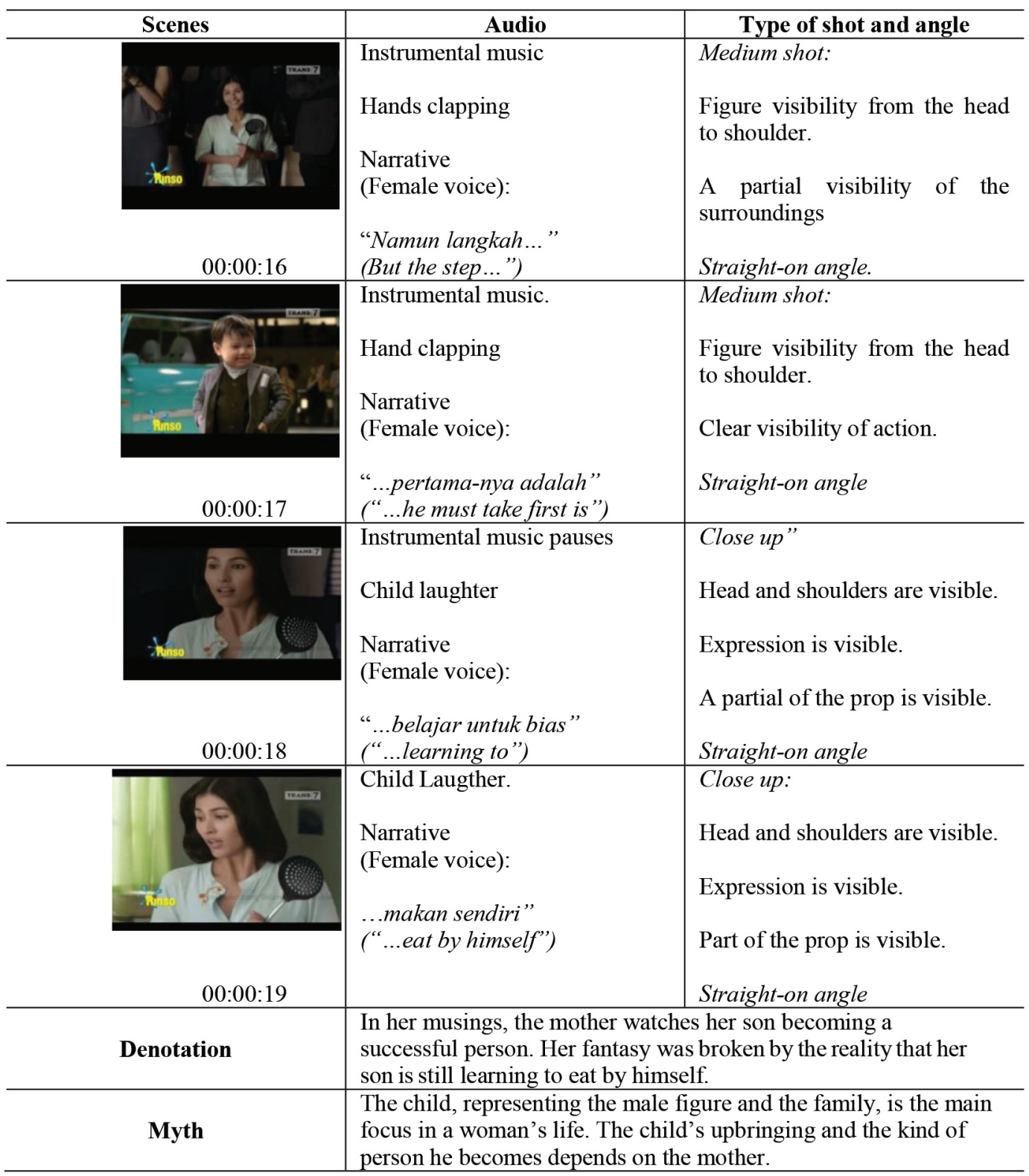


Table 6. Sequence 6

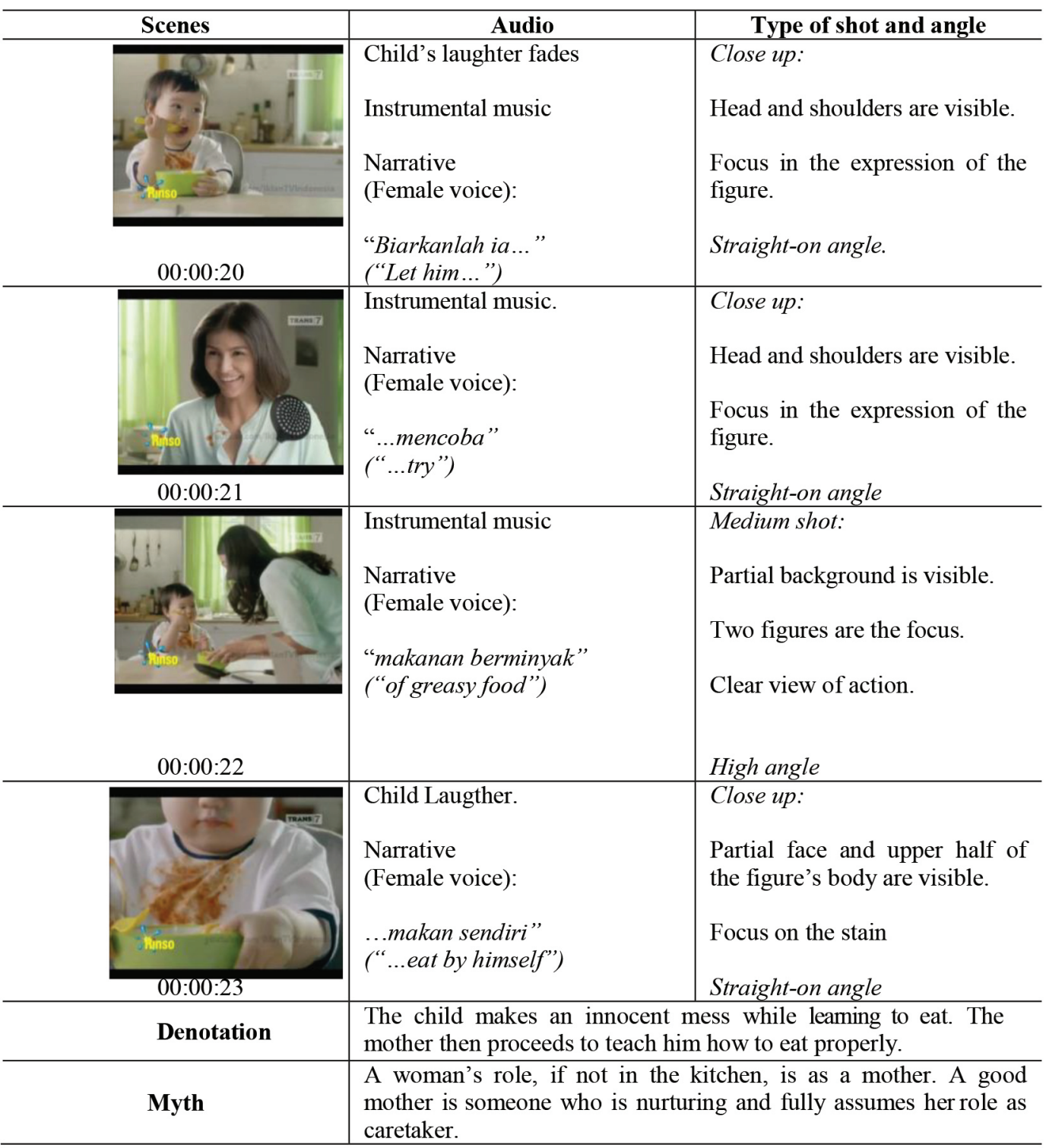


Table 7. Sequence 7

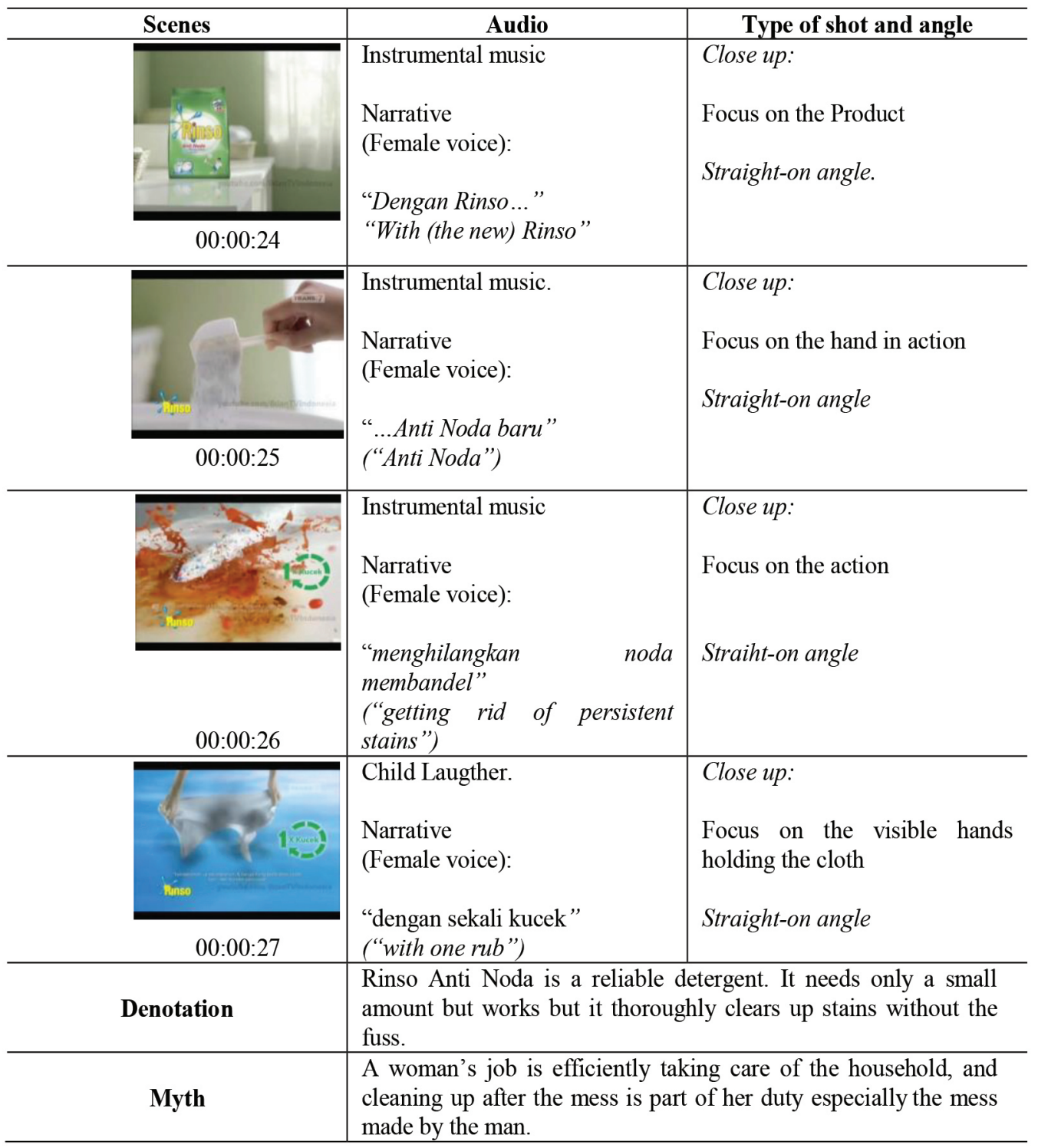


Table 14. Sequence 8

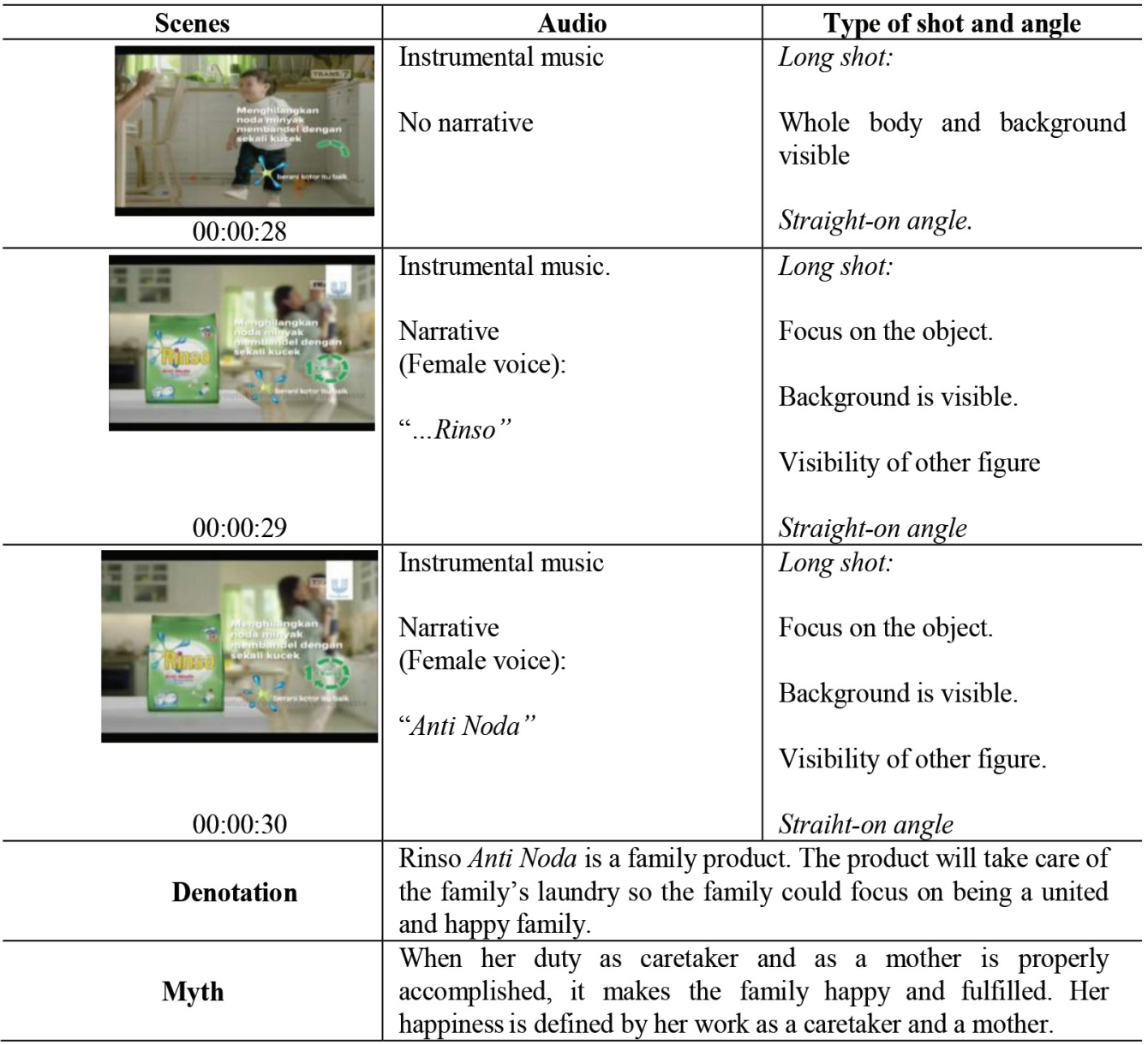

\section{a. Gender Display}

Goffman (1979) has identified six signs to decode gender display based on the relative size, feminine touch, the family, licensed withdrawal, functional ranking, and the ritualization of subordination. The following table contains scenes with explanations gathered from Goffman's Gender Display and descriptions of how the scenes fit the criteria. 


\section{Table 15. Gender Display}

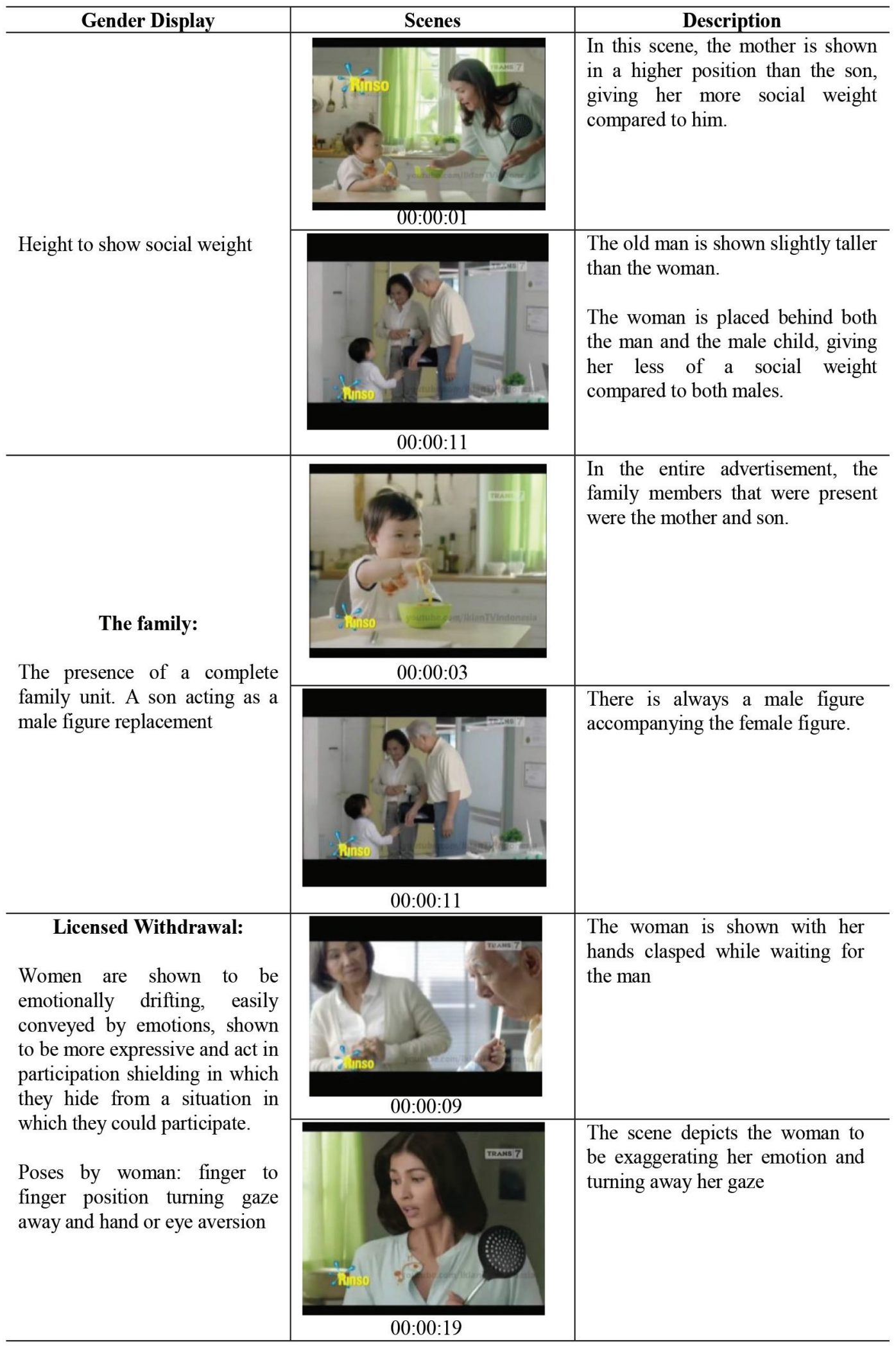




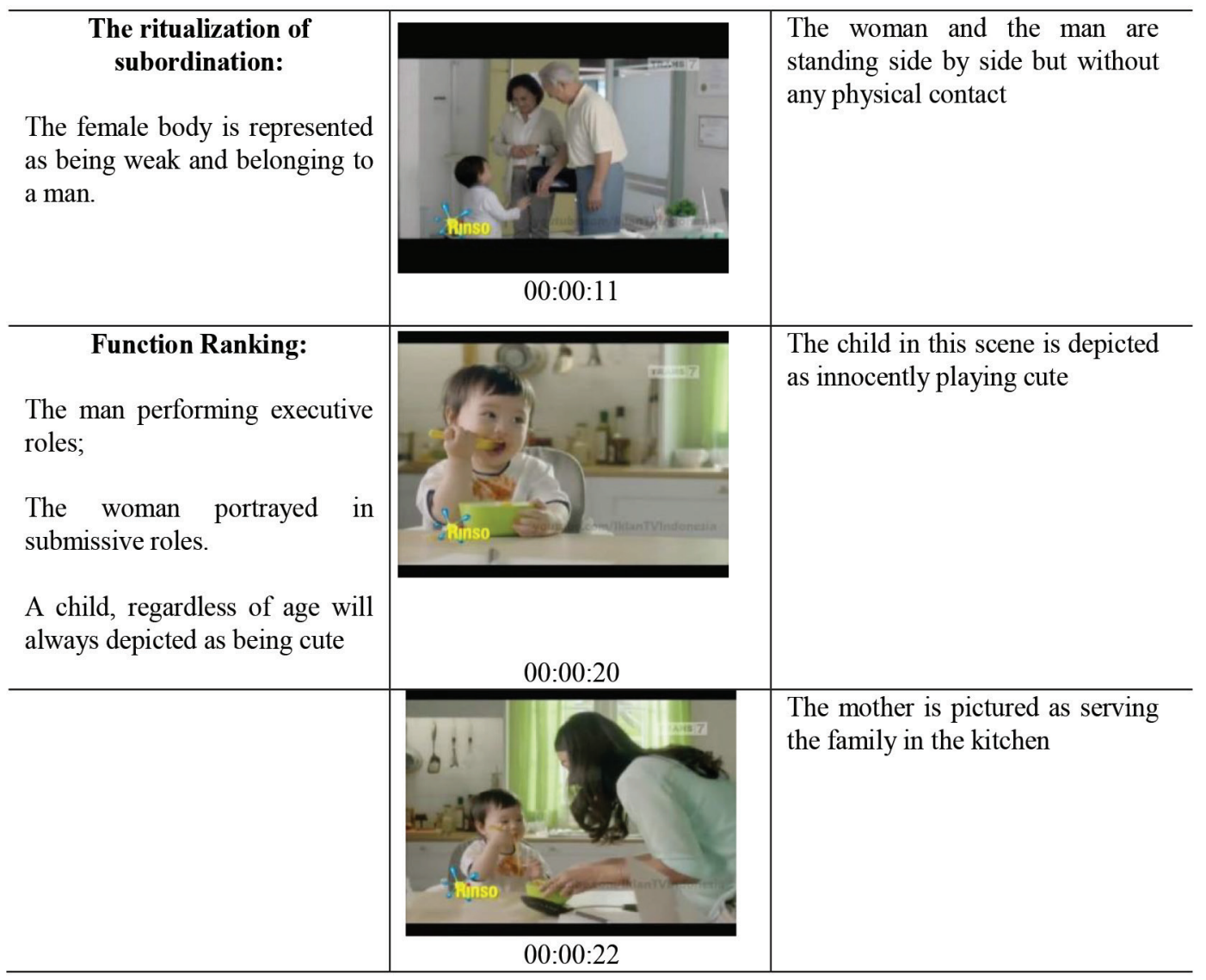

b. Gender Representation in Rinso Anti Noda's 2015 Commercial

The main characters in the family are a mother and a son. The son represents not only the family's child but as also a replacement of the absent male figure (Goffman, 1979). This could be seen from beyond the physicality of the child but from the traditional division of gender roles within the household. The son assumes no domestic responsibility neither is he portrayed to have any (Suasana, 2004). Instead, he is portrayed to have an occupation while the mother is his caretaker. Even when the child reaches success the women never leaves the kitchen. This corresponds to the stereotypical portrayal of gender in which women are associated with a domestic roles, while men are portrayed as persons of career (Efianingrum, 2009).
The women in the advertising has two main roles: the mother and the companion. As a companion, the women in this advertising is always shown to be accompanying the male figure in the scene. They are either standing next to the man or sitting on the sidelines as a supporter. This is a form of subordination that pushes women back and make them fill in the secondary role of an observer and a non-active supporter (Kusumastutie \& Faturochman, 2004). Even as a mother, the woman is merely the family's caretaker and the child's educator. It is the mother's responsibility to make sure that the house and her family looks presentable (Rahmawati, Tripambudi \& Lestari, 2010). As an educator, the child's success in education and building the child's character is also her duty (Idrus, 2011). 
The woman who is also a mother is depicted as a caretaker of the household or the nurturer of the child. In the advertising, this is represented through the physical contact she made. She either caters to and holds her son, or constantly grasps the cooking tool. The cooking tool represents the kitchen. Translated, this means that she never leaves the kitchen, and thus according to the commercial, a woman belongs to the domestic world (Rahmawati, Tripambudi \& Lestari, 2010). Aside from being a wife and a mother, in the commercial there is no other role held by the women. In the commercial, the success of her child depends on her ability to care for the household, in this case, by taking care of the laundry so she could accommodate her son's learning process. Once again, this shows that her fundamental concerns are of the domestic world. Therefore, the commercial shows that a woman's role as a mother is not diverse and is closely tied to the family and the domestic world (Kusumastutie \& Faturochman, 2004).

e. Women Portrayal in the Rinso Anti Noda Commercial and the Ibuism Ideology

In his work Tamagola (1998) mentions five concept of women portrayal in the media: figurine (pigura), a trophy (pinggan), a pillar (pilar), a contest (peraduan) and a socialite (pergaulan). Findings in this study show that the portrayal of women in the Rinso Anti Noda commercial are aligned with three out of five concepts of Tamagola's women portrayal: Trophy (pinggan), Pillar (pilar) and Socialite (pergaulan).

As a trophy, a woman is portrayed as no more than a caretaker and caregiver of the household, whereas as a pillar (pilar), a woman's responsibility lies on the care of the household and children (Rahmawati, Tripambudi \& Lestari, 2010). As a socialite (pergaulan), in the entire sequence of the commercial, the woman is portrayed as a put-together and well-dressed woman. Seen from a socio-cultural perspective, these concepts are parallel to the ibuism ideology. The ideology conditions a women's identity into no more than mothers, caretakers of the household and companions (Suryakusuma, 1987).

In conclusion, within the context of the 2015 Rinso Anti Noda commercial titled "Belajar Untuk Makan Sendiri", women are still represented in subordinate roles. The women's responsibilities are depicted as a mother and caretaker of the household. This depiction is parallel with Tamagola's (1998) concept of trophy (pinggan), pillar (pilar) and socialite (pergaulan). In relation to the sociological and historical aspect of the Indonesian history, it is the manifestation of the ibuism ideology and hegemonic masculinity in the media.

\section{CONCLUSIONS}

The purpose of this research is to analyze and identify the representation of gender in the television advertising, to understand and to study the representation of gender and women in advertising. Rinso Anti Noda's advertisement titled "Belajar Untuk Bisa Makan Sendiri" is used as an object of analysis. Barthes's method of semiotic analysis is employed to identify the signs that lead to answer the proposed research question.

By observation and analysis of the miseen-scéne and the advertising's dialogue, signs of gender representations are able to be identified. The advertising contains a deep and rich context that are not apparent just by scratching the surface. Barthes's method of semiotic is applicable not only on print advertisements but also on television advertisement. Through Barthes's method, the connotation and denotation (myth) meaning are able to be 
analyzed. The detonation analysis enables understanding of the cultural meaning from the advertisement.

The findings conclude that the following combination of visual cues: costume and make-up, setting, framing and figure behavior indicates that gender stereotypes especially the representation of women are present in the advertisement.

While the narrative within the advertisement acts as an amplifier for the shown representations. In the advertising women are portrayed as mothers because they are identified by their domestic duty. This representation has some correlation with the socio-cultural history of Indonesia. The ibuism ideology is still present within the understanding of womanhood and it's used as a stereotype by the media especially in this case to advertise a product. Also as a result of hegemonic masculinity in the media.

\section{REFERENCES}

Allen, G (2003), Critical Thinkers, Routledge, London: United Kingdom.

Anastasi, A (1989), Bidang-Bidang Psikologi Terapan, Rajawali Pers, Depok: Indonesia.

Beasley, C (2008), Rethinking Hegemonic Masculinity in a Globalizing World. Men and Masculinities, Vol. 11 No. 1, pp. 86103.

Berger, A (2000), Media and communication research methods. Sage Publications, New York: USA.

Berliner, T (1999), Hollywood Movie Dialogue and the" Real Realism" of John Cassavetes. Film Quarterly (ARCHIVE), Vol. 52, No. 3, pp. 2.

Budiman, K (1999), Feminogr [a] fi, Pustaka Pelajar, Umbulharjo: Yogyakarta.
Burns, T (1992), Erving Goffman, Routledge, London: United Kingdom.

Bungin, B. S (2007), Penelitian Kualitatif, Kencana, Jakarta: Indonesia.

Chandler, D (2002), Semiotics: The Basics, Routledge, London: United Kingdom.

Chen, H. C., Chiu, H. C., \& Wang, J (2009), Exploring the Elements of A StoryForm Advertising and Its Effectiveness. Retrieved on, 28(03), 2013.

Christomy, T., \& Yuwono, U (2004), Semiotika budaya. Pusat Penelitian Kemasyarakatan dan Budaya, Direktorat Riset dan Pengabdian Masyarakat, Universitas Indonesia.

Courtney, A., \& Lockeretz, S (1971), A Woman's Place: An Analysis of the Roles Portrayed by Women in Magazine Advertisements. Journal of Marketing Research, Vol. 8, No. 1, pp. 92.

Deledalle, G (2000), Charles S. Peirce's Philosophy of Signs: Essays in Comparative Literature.

De Saussure, F (1983), Course in general linguistics, trans. Wade Baskin (New York:Philosophical Library, 1959), 117.

Efianingrum, A (2009), Citra Perempuan dalam Iklan di Televisi. Artikel Humaniora.

Ellis, J. W (1996), The Selling of Gender Identity. In Advertising and Culture: Theoretical Perspectives, 91-103.

Goffman, E (1979), Gender advertisements. Palgrave, London: United Kingdom.

Iriantara, Y (2008), Media, Gender dan Melek Media. Jurnal Universitas Islam Nusantara.

Kareithi, P. J (2014), Hegemonic masculinity in media contents. 
INTERNATIONAL ASSOCIATION FOR MEDIA AND COMMUNICATION RESEARCH. Media and gender: a scholarly agenda for the Global Alliance on Media and Gender. UNESCO, Paris: French.

Kasiyan, M (2008), Manipulasi dan Dehumanisasi Perempuan dalam Iklan, Ombak, Sleman: Yogyakarta.

Kawamoto, K. (Ed.) (2003), Digital journalism: Emerging media and the changing horizons of journalism, Rowman \& Littlefield Publishers, Maryland: USA.

Kotler, P., \& McDougall, G. H (1984), Marketing essentials, Prentice-Hall, New Jersey: USA.

Kusumastutie, N. S. \& Faturochman (2004), Analisis Gender pada Iklan Televisi dengan Metode Semiotika. Jurnal Psikologi, Vol. 2, pp. 130-141.

Lasswell, H. D (1948), The structure and function of communication in society. New York.

Logas, H., \& Muller, D (2005), Miseen-scène Applied to Level Design: Adapting a Holistic Approach to Level Design [online] Digital Research Games Association.

McQuail, D (2010), Mass Communication Theory. Sage Publishing.

Murphy, A (2003), The Dialectical Gaze: Exploring the Subject-Object Tension in the Performances of Women who Strip. Journal of Contemporary Ethnography, Vol. 32, No. 3, pp. 305-335.
Odelia, J (2016), Gender Advertising in Television Commercial: A Semiotic Analysis of the 2015 Rinso Anti Noda Commercial Titled "Belajar Untuk Bisa Makan Sendiri” (Bachelor's Thesis).

Popova, P. D (2010), Gender Stereotypes in Advertising. Retrieved from https://docs.google.com/ viewer?url=http $\% 3 \mathrm{~A} \% 2 \mathrm{~F} \% 2$ Fresearch.bfu.

Rahmawati, D (2014), The Analysis of Ideology and Patriarchal Attitudes in Ronggeng Dukuh Paruk and the Dancer (Doctoral's dissertation). Retrieved from https://www.google.com

Rahmawati, A. S., Tripambudi, S., \& Lestari, P (2010), Bias Gender dalam Iklan Attack Easy di Televisi. Jurnal Ilmu Komunikasi Terakreditasi, Vol. 8, No. 3, pp. 221-232.

Richards, J. I., \& Curran, C. M (2002), Oracles on "advertising": Searching for a definition. Journal of Advertising, Vol. 31, No. 2, pp. 63-77.

Rinso (2016), Tentang Kami. Retrieved March 5, 2016,from https://www.unilever. co.id/brands/our-brands/rinso.html

Russo, J. \& Chaxel, A (2010), How persuasive messages can influence behavior without awareness. Journal of Consumer Psychology, Vol. 20, No. 3, pp. 338-342.

Sari, S (2012), Stereotip, Bahasa, dan Pencitraan Perempuan pada Iklan dalam Perspektif Budaya Populer. Citra Perempuan Dalam Media.

Schramm, W (1964), Mass media and national development: The role of information in the developing countries (No. 25). Stanford University Press. 
Sebeok, T. A (2001), Signs: An introduction to semiotics. University of Toronto Press.

Shields, V (2001), Measuring Up: How Advertising Affects Self-Image. University of Pennsylvania Press.

Siregar, Y. A., \& Mahendro, A. Y (2011), Pencitraan Perempuan di Majalah: Konstruksi Identitas Perempuan Kelas Menengah di Perkotaan. Jurnal Komunitas, Vol. 5, No. 1, pp. 1-24.

Siswati, E (2015), Representasi Domestikasi Perempuan dalam Iklan. Jurnal Ilmu Komunikasi, Vol. 11, No. 2.

Sobur, A (2009), Semiotika komunikasi. Remaja Rosdakarya, Bandung: Indonesia

Suasana, A. A (2004), Hubungan gender dalam representasi iklan televisi. Nirmana, Vol. 3, No. 1.

Suryakusuma, J (2011), State Ibuism. Komunitas Bambu.

Tomagola, T. A (1998), Citra Wanita dalam iklan dalam Majalah Wanita Indonesia.

Tamburaka, A (2012), Agenda Setting Media Massa. Rajawali Press, Bandung: Indonesia.
Vantomme, D., Geuens, M., \& Dewitte, S (2005), How to portray men and women in advertisements? Explicit and implicit evaluations of ads depicting different gender roles.

Vestergaard, T., \& Schrøder, K (1985), The language of advertising. Blackwell, Oxford: United Kingdom

Walker, M. A., Lin, G. I., \& Sawyer, J (2012), An Annotated Corpus of Film Dialogue for Learning and Characterizing Character Style: Proceedings of the Eight International Conference on Language Resources and Evaluation (LREC'12) (pp. 1373-1378). Istanbul: ELRA.

Wulandari, D, \& Candria,M(2012),Pemahaman Kader PKK terhadap Panca Dharma Wanita dalam Konteks Critical Discourse Analysis. Retrieved from https:/docs.google.com/ viewer?url=http $\% 3 \mathrm{~A} \% 2 \mathrm{~F} \% 2 \mathrm{Feprints}$. undip. ac.id $\% 2$ F43116\%2F1\%2FPemahaman_kader_ PKK terhadap_Panca_Dharma_Wanita dalam_Konteks_Critical_Discourse_Analisys. pdf\&pdf=true 